\title{
Simulating ultrafine particle formation in Europe using a regional CTM: contribution of primary emissions versus secondary formation to aerosol number concentrations
}

\author{
C. Fountoukis ${ }^{1}$, I. Riipinen ${ }^{2}$, H. A. C. Denier van der Gon $^{3}$, P. E. Charalampidis ${ }^{4}$, C. Pilinis ${ }^{4}$, A. Wiedensohler ${ }^{5}$, \\ C. O'Dowd ${ }^{6}$, J. P. Putaud ${ }^{7}$, M. Moerman ${ }^{3}$, and S. N. Pandis ${ }^{1,8,9}$ \\ ${ }^{1}$ Institute of Chemical Engineering Sciences, Foundation for Research and Technology Hellas (ICEHT/FORTH), \\ Patras, Greece \\ ${ }^{2}$ Department of Applied Environmental Science \& Bert Bolin Centre for Climate Research, Stockholm University, \\ 11418 Stockholm, Sweden \\ ${ }^{3}$ Netherlands Organisation for Applied Scientific Research TNO, Princetonlaan 6, 3584 CB Utrecht, The Netherlands \\ ${ }^{4}$ Department of Environment, University of the Aegean, University Hill, 81100, Mytilene, Greece \\ ${ }^{5}$ Leibniz Institute for Tropospheric Research, 04318 Leipzig, Germany \\ ${ }^{6}$ School of Physics and Centre for Climate \& Air Pollution Studies, National University of Ireland Galway, University Road, \\ Galway, Ireland \\ ${ }^{7}$ European Commission, Joint Research Centre, Institute of Environment and Sustainability, Ispra, Italy \\ ${ }^{8}$ Department of Chemical Engineering, Carnegie Mellon University, Pittsburgh, PA 15213, USA \\ ${ }^{9}$ Department of Chemical Engineering, University of Patras, Patras, Greece
}

Correspondence to: S. N. Pandis (spyros@andrew.cmu.edu)

Received: 21 April 2012 - Published in Atmos. Chem. Phys. Discuss.: 1 June 2012

Revised: 16 August 2012 - Accepted: 3 September 2012 - Published: 26 September 2012

\begin{abstract}
A three-dimensional regional chemical transport model (CTM) with detailed aerosol microphysics, PMCAMx-UF, was applied to the European domain to simulate the contribution of direct emissions and secondary formation to total particle number concentrations during May 2008. PMCAMx-UF uses the Dynamic Model for Aerosol Nucleation and the Two-Moment Aerosol Sectional (TOMAS) algorithm to track both aerosol number and mass concentration using a sectional approach. The model predicts nucleation events that occur over scales of hundreds up to thousands of kilometers especially over the Balkans and Southeast Europe. The model predictions were compared against measurements from 7 sites across Europe. The model reproduces more than $70 \%$ of the hourly concentrations of particles larger than $10 \mathrm{~nm}\left(N_{10}\right)$ within a factor of 2 . About half of these particles are predicted to originate from nucleation in the lower troposphere. Regional nucleation is predicted to increase the total particle number concentration by approximately a factor of 3 . For particles larger than
\end{abstract}

$100 \mathrm{~nm}$ the effect varies from an increase of $20 \%$ in the eastern Mediterranean to a decrease of $20 \%$ in southern Spain and Portugal resulting in a small average increase of around $1 \%$ over the whole domain. Nucleation has a significant effect in the predicted $N_{50}$ levels (up to a factor of 2 increase) mainly in areas where there are condensable vapors to grow the particles to larger sizes. A semi-empirical ternary sulfuric acid-ammonia-water parameterization performs better than the activation or the kinetic parameterizations in reproducing the observations. Reducing emissions of ammonia and sulfur dioxide affects certain parts of the number size distribution.

\section{Introduction}

The two major processes that add new particles into the atmosphere are direct (primary) emissions and nucleation (secondary particles). Primary particles originate from both anthropogenic sources such as fossil fuel combustion and 
natural sources e.g. sea spray, fires, volcanoes, and windborne dust. Secondary particles are formed through nucleation and condensation of gas-phase species significantly influencing the size distribution and number concentrations of atmospheric aerosols (Kulmala et al., 2001, 2004; Stanier et al., 2004). Secondary particulate matter can also form by in-cloud processes followed by cloud drop evaporation. The fresh nuclei are quite small; the critical cluster diameter beyond which particle growth is thermodynamically favored over evaporation is typically of the order of $1 \mathrm{~nm}$.

Aerosol formation by nucleation is potentially important for the climate of our planet because the newly formed particles can grow through condensation of vapors (e.g. sulfuric acid and ammonia, organics) from a few nanometers up to cloud condensation nuclei $(\mathrm{CCN})$-relevant particle sizes of $\sim 100 \mathrm{~nm}$ or more influencing the formation and properties of clouds. Global model calculations suggest that $\mathrm{CCN}$ concentrations are sensitive to nucleation (Adams and Seinfeld, 2002; Spracklen et al., 2006, 2008; Merikanto et al., 2009). Nucleation also enhances atmospheric levels of ultrafine particles (those with diameter less than $100 \mathrm{~nm}$ ) which are highly mobile within the human body and may be especially harmful to human health (Donaldson et al., 1998, 2002; Sioutas et al., 2005). Despite its importance, our understanding of the processes of formation and growth of atmospheric nanoparticles is currently limited mainly due to the ambiguous role of atmospheric species other than $\mathrm{H}_{2} \mathrm{SO}_{4}$ that could potentially control the frequency and rate of new particle formation events in the lower troposphere and contribute to aerosol growth.

A substantial amount of work has been done for the identification of the dominant nucleation mechanisms in the boundary layer (Vehkamaki et al., 2002, 2004; Lovejoy et al., 2004; Kulmala et al., 2006; Yu, 2006a, b; Eisele et al., 2006). Proposed nucleation mechanisms differ in terms of which gas-phase species aid $\mathrm{H}_{2} \mathrm{SO}_{4}$ in forming the critical cluster. In the most commonly-proposed binary nucleation scheme, the critical cluster is assumed to be composed of $\mathrm{H}_{2} \mathrm{O}$ and $\mathrm{H}_{2} \mathrm{SO}_{4}$, while ternary nucleation theories usually include ammonia $\left(\mathrm{NH}_{3}\right)$ as a third component. Comprehensive simulations of nucleation events observed in sulfur-rich regions like the northeastern US appear to be initiated by formation of gas-phase $\mathrm{H}_{2} \mathrm{SO}_{4}$ via $\mathrm{SO}_{2}$ oxidation but terminated by exhaustion of gas-phase $\mathrm{NH}_{3}$ with ternary sulfatewater-ammonia nucleation appearing to control nucleation (Jung et al., 2008). It is possible that other agents (e.g. organics, amines) may play a similar role under certain conditions (Bonn et al., 2008; Kurten et al., 2008; Metzger et al., 2010; Smith et al., 2010; Zhao et al., 2011; Berndt et al., 2010; Kirkby et al., 2011). Condensation of organic species (Kerminen et al., 2000; Anttila and Kerminen, 2003) or ionenhanced condensation (Laakso et al., 2002) have also been proposed as possible mechanisms controlling atmospheric new particle formation. A strong correlation has been found between measured aerosol nucleation rate and the gas-phase sulfuric acid concentration (Weber et al., 1996; Sihto et al., 2006; Riipinen et al., 2007; Kuang et al., 2008; Nieminen et al., 2009; Paasonen et al., 2009, 2010) in various sites in Europe and the United States. This was confirmed by laboratory experiments (Sipilä et al., 2010) revealing a linear or squared correlation between new particle formation rate and concentration of sulfuric acid. Other recent studies have highlighted the potentially important role of condensable organic compounds triggering nucleation in addition to sulfuric acid (Kerminen et al., 2010; Metzger et al., 2010; Paasonen et al., 2010). Although progress has been made, the mechanism behind new particle formation and growth is still not fully understood.

Due to the important role of ultrafine particles, there have been a number of efforts in modeling new particle formation and growth on a large scale. Jacobson (1997) simulated aerosol dynamics and chemistry in a 3-D CTM tracking both number and mass concentrations with a sectional approach. This study concluded that coagulation can reduce the number and volume concentration of particles less than $0.2 \mu \mathrm{m}$ in diameter both in the presence and absence of modest rates of particle growth while when significant growth occurs, the effect of coagulation is reduced. Sotiropoulou et al. (2006) studied the impact of nucleation on $\mathrm{CN}$ and $\mathrm{CCN}$ concentrations using the regional air quality model UAM-AERO at two European sites and showed that nucleation significantly affects the aerosol size distribution, and can be an important contributor to CCN. Trivitayanurak et al. (2008) used a global model with detailed aerosol microphysics (GEOSCHEM/TOMAS) to simulate the aerosol number concentration and found errors in $N_{10}$ of $40-50 \%$ between $15^{\circ} \mathrm{S}$ and $45^{\circ} \mathrm{S}$ and between $45^{\circ} \mathrm{N}$ and $60^{\circ} \mathrm{N}$ highlighting the need for improved emission inventories. Yu and Luo (2009) simulated particle size distribution with a global model and found good agreement (within a factor of two) for almost all 22 sites around the globe for which at least one full year of $N_{10}$ measurements were available. The comparison, however, was conducted against low time-resolution measurements (annually averaged data). Jung et al. (2010) simulated in-situ ultrafine particle formation in the sulfate rich area of the Eastern United States and conducted a detailed comparison with data from the Pittsburgh air quality study. They found good agreement for particle number concentrations above $3 \mathrm{~nm}$, however they stressed the need for more measurement data representative of different environments, and testing of more nucleation parameterizations. Using the GLOMAP global aerosol microphysics model (Spracklen et al., 2005a, b, 2006), Spracklen et al. (2010) and Reddington et al. (2011) analyzed primary and secondary sources of global particle number concentrations using data from several sites throughout the world while testing different nucleation parameterizations. The size of primary emitted particles was identified as a major source of uncertainty in the global model's predictions. The size distribution of emissions in large-scale models must take into account the size 
distribution of the primary particles at the point of emission as well as the aging that occurs at sub-model grid scales (Pierce et al., 2009). If the grid scale is large (e.g. on the order of $300 \mathrm{~km}$ which is usually the scale of a global model) the model has difficulties in tracking changes in the emitted particle number concentration and size distribution appropriately near sources which could cause large uncertainty in its predictions. Primary ultrafine particles have significant concentration gradients in space and time close to their sources (urban areas, major industrial areas, etc.) and thus regionalscale models are well suited for their description in polluted environments.

To date, regional ultrafine particle modeling studies are in an early stage. Furthermore, particle size distribution measurements from multiple locations during the same time period are scarce while updated particle number emission inventories for wide areas (such as Europe) that could improve model predictions are also rare. For these reasons the effect of primary versus secondary contributions to total particle number concentrations on a regional scale is yet to be elucidated. This is important if we want to correctly attribute the aerosol radiative forcing to different sources or formulate efficient pollution control strategies in large urban environments.

In this paper we use the recently developed threedimensional regional CTM with detailed aerosol microphysics, PMCAMx-UF, along with an extensive set of measurements in Europe, to quantify the contribution of direct emissions and secondary formation to total particle number concentrations. A new particle number emission inventory for the whole European domain was developed for the first time and used in this study. We evaluate the model with surface-based high time resolution measurements from several stations and test different nucleation parameterizations as well as the sensitivity of the model to certain emission changes.

\section{PMCAMx-UF description}

PMCAMx-UF is a newly developed (Jung et al., 2010) three-dimensional chemical transport model that simulates the aerosol number size distribution, in addition to the mass/composition size distribution. The framework of PMCAMx-UF is based on the frameworks of PMCAMx (Gaydos et al., 2007; Karydis et al., 2007) and CAMx (Environ, 2003) air quality models, describing the processes of horizontal and vertical advection, horizontal and vertical dispersion, wet and dry deposition, and gas-phase chemistry. The approach of Fahey and Pandis (2001) is used for the simulation of aqueous-phase chemistry. For the simulation of aerosol microphysics, PMCAMx-UF uses the DMAN model of Jung et al. (2006) which simulates the processes of coagulation, condensation/evaporation, emissions, and nucleation assuming an internally mixed aerosol. DMAN uses the Two-Moment Aerosol Sectional (TOMAS) algorithm of Adams and Seinfeld (2002) in which a sectional approach is used. A key feature of TOMAS is its ability to track two independent moments of the aerosol size distribution for each size bin, the two moments being the aerosol number concentration and mass concentration. The aerosol size distribution is discretized in 41 sections covering the diameter range from approximately $0.8 \mathrm{~nm}$ to $10 \mu \mathrm{m}$. The lowest boundary is at $3.75 \times 10^{-25} \mathrm{~kg}$ of dry aerosol mass per particle. Each successive boundary has twice the mass of the previous one for these 41 size sections. From $10 \mu \mathrm{m}$ to $40 \mu \mathrm{m}$, two additional size sections are used for the description of cloud chemistry. The particle compounds modeled include sulfate, ammonium, nitrate, sodium, chloride, crustal material, water, elemental carbon, primary organic aerosol and four secondary organic aerosol components. Nucleation and condensation rates are calculated simultaneously using the pseudo-steady-state approximation (PSSA) for sulfuric acid proposed by Pierce and Adams (2009) which assumes that sulfuric acid concentration reaches steady state instantaneously during a time step. The performance of PSSA for sulfuric acid was evaluated against a 4th order Runge-Kutta algorithm (Jung et al., 2006, 2010) and was shown to be accurate and computationally efficient. The TOMAS version currently in PMCAMx-UF tracks explicitly sulfate, ammonia, nitrate, organics and water while the rest of the species are currently lumped into one surrogate species that is assumed to be inert. The TOMAS algorithm simulates the condensation/evaporation of sulfuric acid and ammonia independently. As sulfuric acid is assumed to be in pseudo-steadystate, the sulfuric acid mass added to each section is calculated as well as its total concentration. The mass distributed in each section is used to calculate the driving force for the sulfuric acid condensation (Adams and Seinfeld, 2002). Condensation of ammonia is simulated numerically following the approach of Jung et al. (2006). An accommodation coefficient of 0.08 is used, while its vapor pressure on the surface of the acidic particles is assumed to be zero. For the simulation of coagulation, the TOMAS algorithm is used (Eqs. 3 and 4 in Adams and Seinfeld, 2002). TOMAS includes explicit prognostic equations for both aerosol mass and number concentrations in each size bin. The calculation of the coagulation coefficients is based on the wet diameters of the particles which are calculated following the approach of Gaydos et al. (2005). Primary organic aerosol is assumed to be non-volatile in PMCAMx-UF. The simulated contribution of organics to the growth of the fresh nuclei is negligible in PMCAMx-UF because of the relatively high volatility of the corresponding surrogate compounds. As is typical in chemical transport models, an operator-splitting approach is used in PMCAMx-UF, with each process simulated separately for each time step, although another (perhaps more accurate but also more computationally demanding) option is to simultaneously treat nucleation and growth for all species (Jacobson, 2002). 


\subsection{Nucleation parameterizations}

Zhang et al. (2010) intercompared the results of 12 nucleation parameterizations based on various nucleation theories and evaluated them under a variety of atmospheric conditions against lab measurements and a field campaign. Significant differences were found among the nucleation rates calculated with different parameterizations. It was found that among all parameterizations tested, 2 power law mechanisms (one activation type nucleation parameterization and one of kinetic type) and one binary nucleation parameterization are the most plausible nucleation parameterizations for applications in the planetary boundary layer of polluted sulfate-rich urban areas. In this work three nucleation theories are tested along with their corresponding parameterizations for the simulation of new particle formation. The base case nucleation mechanism used here is based on the ternary $\mathrm{H}_{2} \mathrm{SO}_{4}-\mathrm{NH}_{3}$ $\mathrm{H}_{2} \mathrm{O}$ nucleation parameterization of Napari et al. (2002). The Napari et al. (2002) ternary nucleation parameterization has been shown to overpredict ultrafine number concentrations during nucleation events (Gaydos et al., 2005; Yu, 2006a, b; Jung et al., 2006; Merikanto et al., 2007; Zhang et al., 2010) and thus a scaling factor of $10^{-6}$ was applied to the nucleation rate following Jung et al. (2010).

The activation parameterization is also tested, in which the particle formation rate is proportional to the gas phase sulfuric acid concentration based on a semi-empirical fit to atmospheric data:

$J_{\text {act }}=A\left[\mathrm{H}_{2} \mathrm{SO}_{4}\right]$

where $J_{\text {act }}$ is the formation rate $\left(\mathrm{cm}^{-3} \mathrm{~s}^{-1}\right)$ of stable clusters and $A$ is a nucleation rate coefficient $\left(\mathrm{s}^{-1}\right)$. The value of $A$ varies both spatially and temporally for reasons which are not well understood to date. Analysis of measurement data shows that $A$ could range from approximately $10^{-7}$ to $10^{-5}$ $\mathrm{s}^{-1}$ (Riipinen et al., 2007; Sihto et al., 2006). We use a value of $A=2 \times 10^{-6} \mathrm{~s}^{-1}$ following Spracklen et al. (2006) and Kulmala et al. (2006) and a critical (nucleated) cluster size of $1 \mathrm{~nm}$ in diameter.

Finally, the kinetic approach is also used, which is based on a square dependence of the new particle formation rate on the sulfuric acid concentration, and the semi-empirically determined coefficient $k$ (McMurry and Friedlander, 1979; Kulmala et al., 2006):

$J_{\text {kin }}=k\left[\mathrm{H}_{2} \mathrm{SO}_{4}\right]^{2}$

Similarly to the coefficient $A$, the value of $k$ has been shown to be highly variable (Riipinen et al., 2007; Sihto et al., 2006). A value of $k=2.6 \times 10^{-13} \mathrm{~cm}^{-3} \mathrm{~s}^{-1}$ is used here and the nucleated particles are assumed to be $2 \mathrm{~nm}$ (Nieminen et al., 2009; Sihto et al., 2006).

\subsection{Particle number/mass emissions}

A new Pan-European anthropogenic Particle Number Emission Inventory (Kulmala et al., 2011) was developed for the first time covering the particles size range of $10-300 \mathrm{~nm}$ as well as the Pan-European Carbonaceous Aerosol Inventory which provided emissions of larger particles (Kulmala et al., 2011). Hourly gridded anthropogenic and biogenic emissions that were developed for the European region included both gases and primary particulate matter. Volatile organic compounds are split based on the speciation approach proposed by Visschedijk et al. (2007). Anthropogenic gas emissions that were used to develop the gridded fields include land emissions from the GEMS dataset (Visschedijk et al., 2007) as well as international shipping emissions. A variety of emission sources are identified in the anthropogenic inventories, including industrial, domestic, agricultural and traffic.

Three different datasets are combined in order to produce the biogenic gridded emissions for the model. Emissions from ecosystems are produced by MEGAN (Model of Emissions of Gases and Aerosols from Nature) (Guenther et al., 2006). MEGAN inputs include the plant functional type, the leaf area index, various chemical species emission factors and weather data provided by the WRF (Weather Research and Forecasting) model (Skamarock et al., 2005). Since sea surface covers a considerable portion of the domain, the marine aerosol emission model developed by O'Dowd et al. (2008) has been used. Wind speed data fields from WRF and chlorophyll $a$ concentrations are the inputs needed for the marine aerosol model. Finally wildfire emissions for the May 2008 period were also included (Sofiev et al., 2008a, b). Table 1 shows a summary of particle number emission rates from the different sources for the European domain during May 2008. A summary of the $\mathrm{PM}_{10}$ mass emission rates is given in Fountoukis et al. (2011).

\subsection{Meteorological input fields}

Meteorological inputs to PMCAMx-UF include horizontal wind components, vertical diffusivity, temperature, pressure, water vapor, clouds and rainfall. The meteorological model WRF (Skamarock et al., 2005) was used to create the above inputs. WRF was driven by static geographical data and dynamic meteorological data (near real-time and historical data generated by the Global Forecast System $(1 \times 1 \mathrm{deg}))$. 27 sigma-p layers up to 0.1 bars were used in the vertical dimension. Each layer of PMCAMx-UF is aligned with the layers used in WRF. The WRF May 2008 run was periodically re-initialized (every 3 days) to ensure accuracy in the corresponding fields that are used as inputs in PMCAMx-UF.

\section{Model application}

The PMCAMx-UF modeling domain covers a $5400 \times 5832 \mathrm{~km}^{2}$ region in Europe with 150 cells in 
Table 1. Emission totals of gas-phase species (in ktons month ${ }^{-1}$ ) and particle number (in particles $\mathrm{m}^{-2} \mathrm{~h}^{-1}$ ) for the European domain during May 2008.

\begin{tabular}{|c|c|c|c|c|c|c|c|c|c|}
\hline \multirow[t]{2}{*}{ Species } & \multirow[t]{2}{*}{$\mathrm{CO}$} & \multirow[t]{2}{*}{ NO } & \multirow[t]{2}{*}{$\mathrm{SO}_{2}$} & \multirow[t]{2}{*}{$\mathrm{NH}_{3}$} & \multicolumn{3}{|c|}{ Biogenic VOCs } & \multirow[t]{2}{*}{$\mathrm{PN}_{1-100}^{3}$} & \multirow[t]{2}{*}{$\mathrm{PN}_{>100}^{4}$} \\
\hline & & & & & Isop. & $\mathrm{MT}^{1}$ & ovOC $^{2}$ & & \\
\hline Anthropogenic & 3682 & 1461 & 1675 & 501 & - & - & 1291 & $7.6 \times 10^{9}$ & $9.7 \times 10^{9}$ \\
\hline Natural (MEGAN) & 439 & 24 & - & - & 892 & 474 & 495 & - & - \\
\hline Natural (Sea salt) & - & - & - & - & - & - & - & $0.5 \times 10^{9}$ & $2.5 \times 10^{9}$ \\
\hline Natural (Fires) & 768 & 22 & 3 & 11 & - & - & 11 & $6.6 \times 10^{9}$ & $2.6 \times 10^{9}$ \\
\hline
\end{tabular}

the $\mathrm{x}$ - and 162 cells in the $\mathrm{y}$-direction, with a $36 \times 36 \mathrm{~km}$ grid resolution and 14 vertical layers covering approximately $6 \mathrm{~km}$ in the z-direction. PMCAMx-UF was set to perform simulations on a rotated polar stereographic map projection. The first two days of each simulation were excluded from the analysis to limit the effect of the initial conditions on the results.

During May 2008 an intensive campaign of particle number size distribution measurements was performed in Europe as part of the European Aerosol Cloud Climate and Air Quality Interactions (EUCAARI) project (Kulmala et al., 2009, 2011). The model results are compared against hourly mean values from 7 measurement ground sites in Aspvreten (Sweden), Cabauw (Netherlands), Hyytiala (Finland), Ispra (Italy), Mace Head (Ireland), Melpitz (Germany), and Vavihill (Sweden). All data have been extracted from the EUSAAR (European Supersites for Atmospheric Aerosol Research) database which follows a standardized protocol of instrument maintenance, measurement procedures and data delivery in common format.

The Aspvreten site $\left(58.8^{\circ} \mathrm{N}, 17.38^{\circ} \mathrm{E}\right)$ is located $70 \mathrm{~km}$ south west of Stockholm. The station is considered to be representative of the regional background in Mid-Sweden situated about $2 \mathrm{~km}$ from the coast in a rural area surrounded by forest.

The Cabauw site is located at a rural area in the western part of the Netherlands $\left(51.97^{\circ} \mathrm{N}, 4.93^{\circ} \mathrm{E}\right)$. The nearby region is agricultural and the North Sea is more than $50 \mathrm{~km}$ away to the WNW.

In Hyytiala, the measurements were performed at the SMEAR II (Station for Measuring Forest EcosystemAtmosphere Relations II) station $\left(61.85^{\circ} \mathrm{N}, 24.28^{\circ} \mathrm{E}\right)$ located in Southern Finland. The site is considered to represent typical regional background conditions for higher latitudes of Europe, and the air masses are usually influenced by European pollution or clean Arctic air.

The Ispra site $\left(45.8^{\circ} \mathrm{N}, 8.6^{\circ} \mathrm{E}\right)$ is located in a semi-rural area by the Eastern shore of a sub-alpine lake in Northern Italy. The station is several tens of kilometers away from large emission sources like intense road traffic or big factories.

Melpitz is an atmospheric research station in Eastern Germany, $40 \mathrm{~km}$ northeast of Leipzig $\left(51.54^{\circ} \mathrm{N}, 12.93^{\circ} \mathrm{E}\right)$. The station is mainly surrounded by agricultural pastures and forests. Atmospheric aerosol observations at the Melpitz site can be regarded as representative of the regional central European aerosol, confirmed on the basis of a multiple site comparison within the German Ultrafine Aerosol Network (Birmili et al., 2009).

The Mace Head site $\left(53.32^{\circ} \mathrm{N}, 9.88^{\circ} \mathrm{W}\right)$ is located on the west coast of Ireland on a hilly area (height around $35 \mathrm{~m}$ ) surrounded by a number of small lakes and is exposed to the North Atlantic ocean. It is $90 \mathrm{~km}$ west of Galway (population approximately 60000 ) which is the nearest major city.

The Vavihill site $\left(56.01^{\circ} \mathrm{N}, 13.15^{\circ} \mathrm{E}\right)$ is a continental regional background site in south Sweden with no major local sources of pollution. However, there are several densely populated areas nearby such as Copenhagen (Denmark, 2 million inhabitants, $60 \mathrm{~km}$ southwest), Malmo (Sweden, 250000 inhabitants, $50 \mathrm{~km}$ south). There is also intense ship traffic in the strait between Sweden and Denmark.

More detailed information on the location and characteristics of each site is given elsewhere (Asmi et al., 2011; Manninen et al., 2010). Particle size distribution measurements at all sites were made using either a Differential Mobility Particle Sizer (DMPS) or a Scanning Mobility Particle Sizer (SMPS), both classifying particles above $10 \mathrm{~nm}$ in mobility diameter. The Intensive Observation Period (IOP) of May 2008 includes some more surface-based measurement stations in Europe. For this study we have excluded the highaltitude $(>800 \mathrm{~m}$ ) sites (since this study focuses on particle number concentration in the boundary layer) and sites from which limited data (less than a week) were available throughout the whole month of May. 

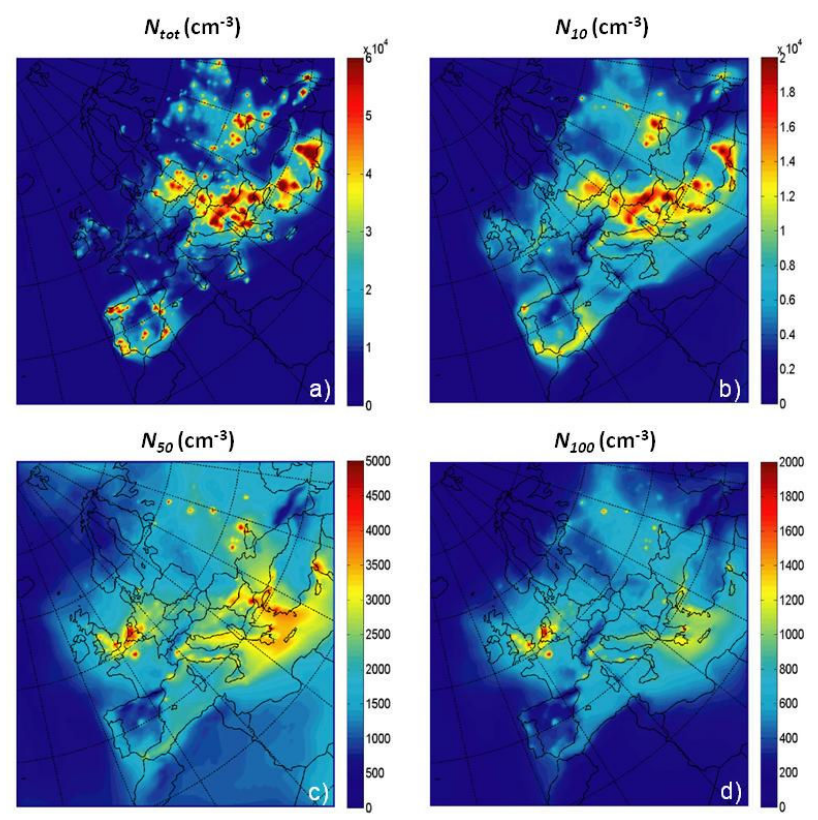

Fig. 1. Ground level average number concentrations $\left(\mathrm{cm}^{-3}\right)$ predicted during May 2008 for (a) all particles $\left(N_{\text {tot }}\right)$ and particles above (b) $10 \mathrm{~nm}\left(N_{10}\right)$, (c) $50 \mathrm{~nm}\left(N_{50}\right)$ and (d) $100 \mathrm{~nm}\left(N_{100}\right)$. Different scales are used.

\section{Model predictions over Europe}

Figure 1 shows PMCAMx-UF basecase (using the ternary nucleation parameterization) predictions of ground level average number concentration for all particles $\left(N_{\text {tot }}\right)$ and for particle diameters above $10 \mathrm{~nm}\left(N_{10}\right), 50 \mathrm{~nm}\left(N_{50}\right)$ and $100 \mathrm{~nm}\left(N_{100}\right)$ during May 2008 . The $N_{50}$ and $N_{100}$ concentrations represent two proxies for $\mathrm{CCN}$-related aerosol number concentrations. $N_{\text {tot }}$ is the total particle number concentration that the model calculates and $N_{10}$ is calculated since it can be directly compared against DMPS (or SMPS) measurements. Nucleation is predicted to start each event day from the east and move toward the west following the evolution of photochemical activity. Predicted total particle number concentrations in Europe range from less than $10000 \mathrm{~cm}^{-3}$ over mainly marine regions where primary particle emissions are low, up to approximately $100000 \mathrm{~cm}^{-3}$ over some continental regions with strong nucleation events. On a domain average basis, the model predicts $9000 \mathrm{~cm}^{-3}$ for $N_{\text {tot }}, 4200 \mathrm{~cm}^{-3}$ for $N_{10}, 1500 \mathrm{~cm}^{-3}$ for $N_{50}$ and $400 \mathrm{~cm}^{-3}$ for $N_{100}$ during the month of May. The spatial distribution of particle number concentration for all particles and particles above $10 \mathrm{~nm}$ is quite similar while for particles above 50 and $100 \mathrm{~nm}$ is quite different. The spatial pattern of $N_{\text {tot }}$ and $N_{10}$ follows the one of the precursor gas $\mathrm{SO}_{2}$, while $N_{50}$ and $N_{100}$ follow the spatial pattern of fine PM mass concentration (not shown here). Highest particle number concentrations (more than
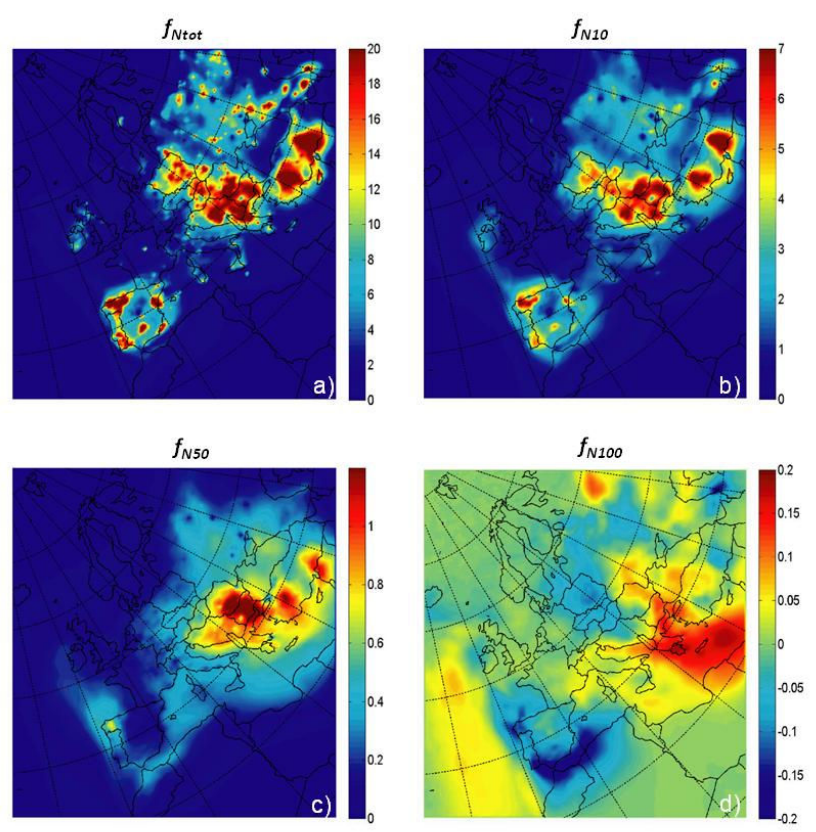

Fig. 2. Ground level average fractional increase of number concentration due to nucleation predicted during May 2008 for (a) all particles $\left(f_{N_{\text {tot }}}\right)$, particles above (b) $10 \mathrm{~nm}\left(f_{N_{10}}\right)$, (c) $50 \mathrm{~nm}\left(f_{N_{50}}\right)$ and (d) $100 \mathrm{~nm}\left(f_{N_{100}}\right)$. Different scales are used.

$100000 \mathrm{~cm}^{-3}$ ) are predicted over Bulgaria, Bosnia, south Romania, and Turkey.

A simulation with nucleation turned off $(J=0$ at all times) was performed. The average fractional increase of particle number concentration due to nucleation defined as $f=\left(N_{\mathrm{N}}-N_{\mathrm{O}}\right) / N_{\mathrm{O}}$, where $N_{\mathrm{N}}$ and $N_{\mathrm{O}}$ are the predicted particle number concentrations with nucleation turned on and off, respectively is shown in Fig. 2. The average fractional increases are 3.0, 1.1, 0.2 and 0.005 for the $N_{\text {tot }}, N_{10}, N_{50}$ and $N_{100}$, respectively, over the whole domain during May 2008 and the spatial pattern of these increases (mainly for $N_{\text {tot }}$ and $N_{10}$ ) are similar to the corresponding average concentrations. Major nucleation areas include Turkey, Northern Spain, Romania, Bulgaria and Serbia while more localized new particle formation events are predicted over Estonia, Russia and South Spain. The model predicts that nucleation increases the total particle number concentration by a factor of 20 or more in some of these large areas and by a factor of 6 or 7 for particles larger than $10 \mathrm{~nm}$. For $N_{50}$, aerosol nucleation is responsible for an increase of more than $100 \%$ in Southeast Europe. Over some marine areas (e.g. the eastern Mediterranean and across the coasts of Portugal and Spain) nucleation is predicted to significantly increase $N_{\text {tot }}$ and $N_{10}$ and to a less extent $N_{50}$. Interestingly, the situation is different for $N_{100}$. New particle formation events are predicted to increase the number concentration of particles larger than $100 \mathrm{~nm}$ by up to $20 \%$ over the Eastern Mediterranean and continental Greece. A simultaneous decrease of $N_{100}$ is predicted over 
western Mediterranean and the north coast of Spain. This is because nucleation in this area produces a lot more particles compared to the Eastern Mediterranean (Fig. 1a) and thus the condensing material (sulfuric acid, etc) is distributed to many more particles than in the Eastern Mediterranean, preventing particles from growing to large sizes. This was also predicted for the Eastern US coast and the Gulf of Mexico (Jung et al., 2010).

We have kept the model boundary conditions constant during the simulation with nucleation turned-off. Therefore the sensitivity calculated refers to nucleation taking place within the model domain and not outside. This for example includes nucleation in the boundary layer and the lower troposphere but not in the upper troposphere.

\section{Comparison with field data}

The prediction skill of PMCAMx-UF is quantified in terms of the normalized mean bias (NMB), the normalized mean error (NME), and the percent within a factor of 2 . The prediction skill metrics of PMCAMx-UF against the hourly ground measurements from 7 stations are summarized in Table 2. Scatter plots of the comparison for hourly concentration of particles larger than 10,50 and $100 \mathrm{~nm}$ are shown in Fig. 3. Overall, the model agreement with the particle number concentration ground measurements is encouraging even at this hourly timescale. More than $70 \%$ of the (hourly) data points for $N_{10}$ and $N_{50}$ are predicted within a factor of 2. Predictions of $N_{10}$ are subject to scatter (NME $\left.=57 \%\right)$ but are not biased $(\mathrm{NMB}=-2 \%)$. Both $N_{50}$ and $N_{100}$ are systematically underpredicted by the model with a mean normalized bias of -34 and $-55 \%$, respectively. The systematic underprediction for $N_{50}$ is higher at the more polluted sites (Ispra, Melpitz, Cabauw), while the NMB drops below $20 \%$ at the remote sites (Mace Head, Hyytiala, Aspvreten, Vavihill). $N_{100}$ is biased low at most sites. There are several possible sources of bias in our model predictions including emission rate errors in the particle size distribution, the use of a specific nucleation mechanism, errors in the growth of ultrafine particles due to organics, emission errors in either the anthropogenic or biogenic emissions or errors in the meteorological input, etc. Some of these are explored in more detail in the subsequent sections. Reddington et al. (2011) reported an underprediction in the above sites during the same period mostly in the range $10-80 \mathrm{~nm}$ while using a different emission inventory. Spracklen et al. (2010) also found a large systematic underprediction ( $\mathrm{NMB}=-74 \%)$ of $\mathrm{CN}$ concentrations in the continental BL unless the number emission of anthropogenic primary particles was increased or a mechanism (either the activation or kinetic) that results in particle formation in the BL was included.

Figure 4 shows timeseries of particle number concentration predicted and observed for particles above 10 and $50 \mathrm{~nm}$ during May 2008. Model results shown include a simula-
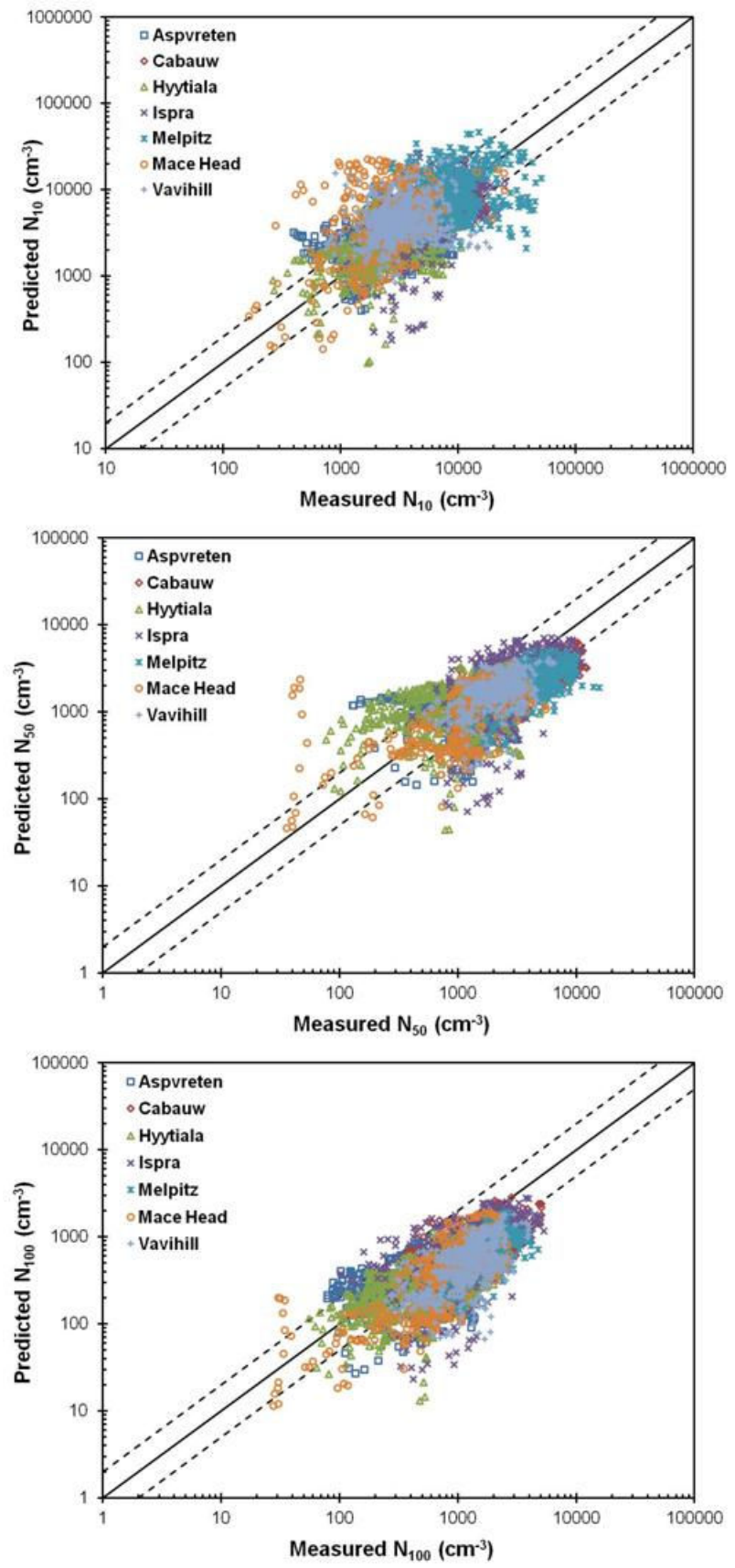

Fig. 3. Comparison of predicted vs. observed particle number concentrations $\left(\mathrm{cm}^{-3}\right)$ above 10,50 and $100 \mathrm{~nm}$ from 7 measurement stations during May 2008. Each point corresponds to a 1-h average value. Also shown the $1: 1,2: 1$ and $1: 2$ lines.

tion with the ternary nucleation mechanism and a simulation where nucleation was turned off. The concentration peaks in $N_{10}$ in Fig. 4 are due to nucleation events while the concentration is much lower during days without nucleation. In Melpitz the basecase simulation predicts frequent nucleation events in agreement with the observations. The model 
predicts that direct emissions contribute only $30 \%$ to $N_{10}$ in Melpitz with the rest coming from aerosol nucleation. Although $N_{10}$ is well predicted by the model, $N_{50}$ (and $N_{100}$ ) are underpredicted in Melpitz. The same is seen in Cabauw indicating possible errors in the assumed size distribution of the emissions or the growth process. Interestingly, nucleation is predicted to significantly affect $N_{50}$ only in sites that are influenced by local sources and have high aerosol number concentrations, namely in Melpitz $(+33 \%)$, Cabauw $(+14 \%)$ and Ispra $(+11 \%)$. In Cabauw and Ispra the predicted contribution of nucleation to particle number concentrations is lower compared to Melpitz. Including nucleation in the simulation in these two sites increases $N_{10}$ by approximately $50 \%$ bringing the predictions closer to the measured values. Particle number concentrations measured in the 2 remote sites of Hyytiala and Aspvreten are the lowest among all sites, in agreement with the model predictions. Nucleation according to the model does not significantly affect $N_{50}$ in these 2 remote sites $(+5 \%$ on average in both sites). However, this is the result of the weak contribution of secondary organics to the growth of the fresh particles in the model. This effect is not well understood (Pierce et al., 2011) and therefore the contribution of nucleation to $N_{50}$ levels in these areas is probably underestimated by PMCAMx-UF. In Mace Head the model overestimates the frequency of nucleation thus overpredicting $N_{10}$ during some days. $N_{50}$ is well predicted by the model during most of the days in the 4 remote sites of Mace Head, Aspvreten, Hyytiala and Vavihill, contrary to the more polluted sites of Cabauw, Ispra and Melpitz in which the model systematically underpredicts both $N_{50}$ and $N_{100}$.

\subsection{Sensitivity to nucleation mechanisms}

Reproduction of the temporal and geographical variation of particle number concentration on an hourly scale is a challenge for all CTMs. In Fig. 5 we compare the three nucleation parameterizations tested against observed average diurnal profiles from all sites. Clearly, use of the kinetic mechanism fails to reproduce the observed diurnal variation, significantly over-predicting aerosol number concentrations at all sites. This is in contrast to Spracklen et al. (2010) who found the same level of model agreement with observations when using either the kinetic or the activation nucleation parameterizations. In Melpitz and Ispra, where the model predicts frequent nucleation events in agreement with the observations, the kinetic mechanism predicts up to 2-3 times higher number concentrations significantly overpredicting the intensity of these events. At the less polluted sites, the kinetic mechanism predicts strong nucleation events especially in the afternoon hours that did not occur. In Melpitz the ternary and activation mechanisms perform practically the same, both correctly predicting the occurrence of the events but delaying their onset by on average $2 \mathrm{~h}$. In Ispra and Cabauw, the ternary scheme performs slightly better than the activa-
Table 2. Prediction skill metrics of PMCAMx-UF against hourly ground measurements of particle number concentration from 7 stations during May 2008.

\begin{tabular}{|c|c|c|c|c|c|}
\hline & $\begin{array}{r}\text { Mean } \\
\text { Observed } \\
\left(\mathrm{cm}^{-3}\right)\end{array}$ & $\begin{array}{r}\text { Mean } \\
\text { Predicted } \\
\left(\mathrm{cm}^{-3}\right)\end{array}$ & $\begin{array}{r}\mathrm{NMB} \\
(\%)\end{array}$ & $\begin{array}{r}\mathrm{NME} \\
(\%)\end{array}$ & $\begin{array}{r}\text { Percent } \\
\text { within a } \\
\text { factor of } 2\end{array}$ \\
\hline \multicolumn{6}{|c|}{ Aspvreten } \\
\hline$N_{10}$ & 2200 & 2700 & 20 & 56 & 72 \\
\hline$N_{50}$ & 1400 & 1300 & -12 & 42 & 73 \\
\hline$N_{100}$ & 570 & 380 & -39 & 54 & 58 \\
\hline \multicolumn{6}{|c|}{ Cabauw } \\
\hline$N_{10}$ & 7580 & 6500 & -14 & 31 & 88 \\
\hline$N_{50}$ & 4600 & 2730 & -41 & 45 & 70 \\
\hline$N_{100}$ & 1900 & 1020 & -47 & 50 & 55 \\
\hline \multicolumn{6}{|c|}{ Hyytiala } \\
\hline$N_{10}$ & 2600 & 2050 & -16 & 50 & 70 \\
\hline$N_{50}$ & 1170 & 1270 & 10 & 56 & 62 \\
\hline$N_{100}$ & 490 & 330 & -39 & 47 & 69 \\
\hline \multicolumn{6}{|c|}{ Ispra } \\
\hline$N_{10}$ & 7800 & 7300 & -30 & 56 & 76 \\
\hline$N_{50}$ & 3900 & 2700 & -47 & 58 & 70 \\
\hline$N_{100}$ & 1750 & 1000 & -66 & 69 & 53 \\
\hline \multicolumn{6}{|c|}{ Mace Head } \\
\hline$N_{10}$ & 3200 & 5590 & 79 & 98 & 65 \\
\hline$N_{50}$ & 1770 & 1420 & -18 & 35 & 76 \\
\hline$N_{100}$ & 920 & 510 & -44 & 47 & 55 \\
\hline \multicolumn{6}{|c|}{ Melpitz } \\
\hline$N_{10}$ & 9500 & 10280 & -2 & 56 & 67 \\
\hline$N_{50}$ & 4700 & 2400 & -48 & 50 & 53 \\
\hline$N_{100}$ & 1700 & 800.0 & -56 & 57 & 37 \\
\hline \multicolumn{6}{|c|}{ Vavihill } \\
\hline$N_{10}$ & 3600 & 5130 & 33 & 68 & 70 \\
\hline$N_{50}$ & 2300 & 1900 & -19 & 29 & 90 \\
\hline$N_{100}$ & 1300 & 600.0 & -57 & 57 & 46 \\
\hline \multicolumn{6}{|c|}{ Overall } \\
\hline$N_{10}$ & 5640 & 5480 & -2 & 57 & 72 \\
\hline$N_{50}$ & 2960 & 1930 & -34 & 48 & 70 \\
\hline$N_{100}$ & 1380 & 620.0 & -55 & 58 & 53 \\
\hline
\end{tabular}

tion one in predicting $N_{10}$ during evening and night hours, but both under-predict $N_{10}$ in the morning (between 9 am and 12 noon) which could also be due to emission rate errors during these rush hours. With the exception of Hyytiala where the ternary and activation schemes perform equally well, in all other remote sites the ternary mechanism performs better. In Hyytiala and Mace Head the model correctly predicts an increase of $N_{10}$ at the right time (afternoon), however in 

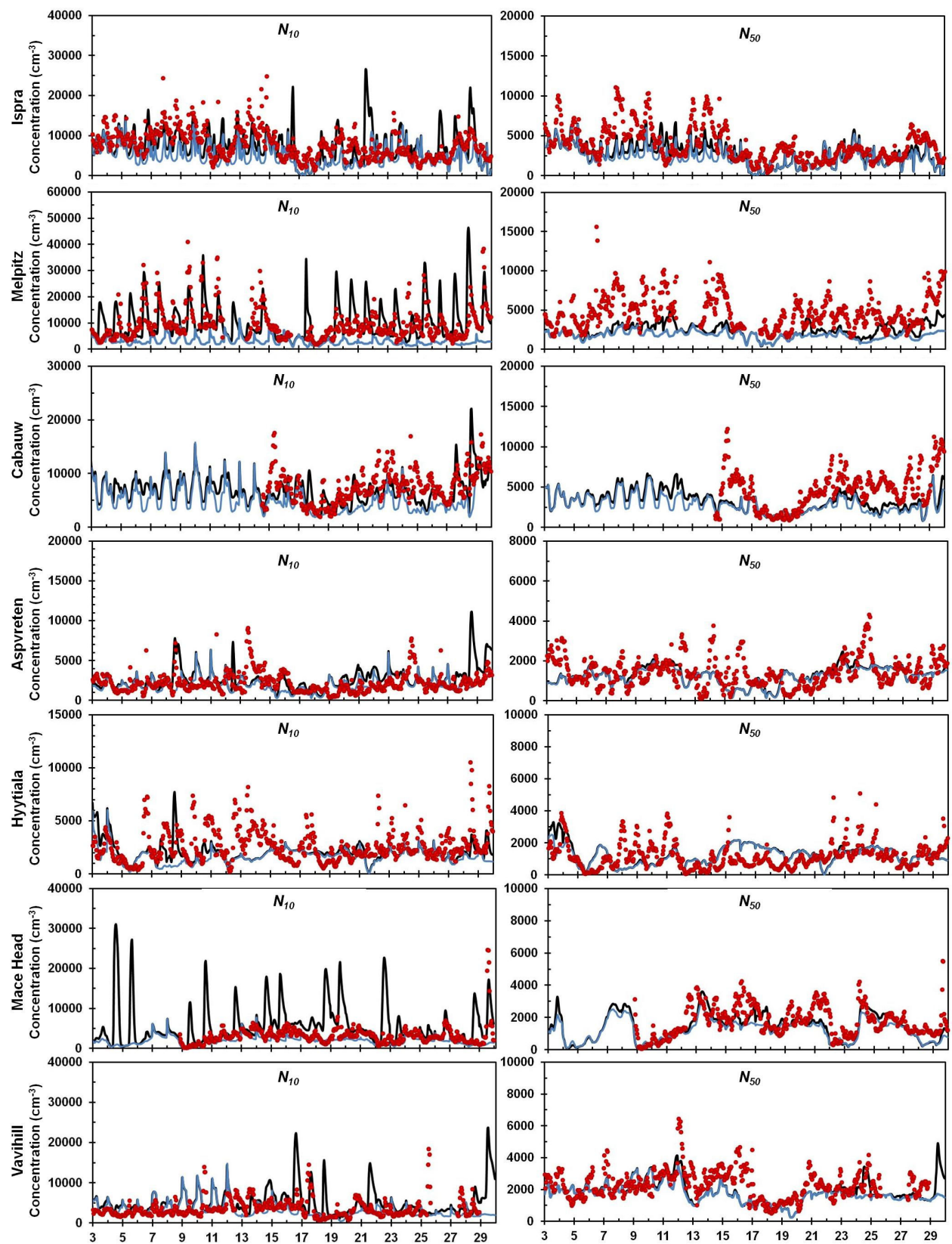

Fig. 4. Timeseries comparison of predicted (ternary mechanism: black line, nucleation turned off: blue line) vs. observed (red dots) particle number concentrations $\left(\mathrm{cm}^{-3}\right)$ above 10 and $50 \mathrm{~nm}$ in 7 measurement stations during May 2008. Different scales are used.

Vavihill the observed peak value of $N_{10}$ is predicted by all mechanisms 3 hours later. Overall, the ternary mechanism predictions are closer to the observed values than the activation scheme predictions. Also, results from all 3 mechanisms suggest that a more careful consideration of the diurnal variation of the particle number emission inventory is needed. Errors in the temporal representation of number concentrations could also be partly attributed to errors in meteorological fields or sub-grid processes that the model cannot capture due to its grid resolution. The growth mechanism can also affect the timing of the $N_{10}$ increase during nucleation event days.

\subsection{Predicted growth rates - sensitivity to organic vapor condensation}

The rate at which the newly formed aerosol population grows was calculated from the model predictions of particle number concentration based on the "maximum concentration" 

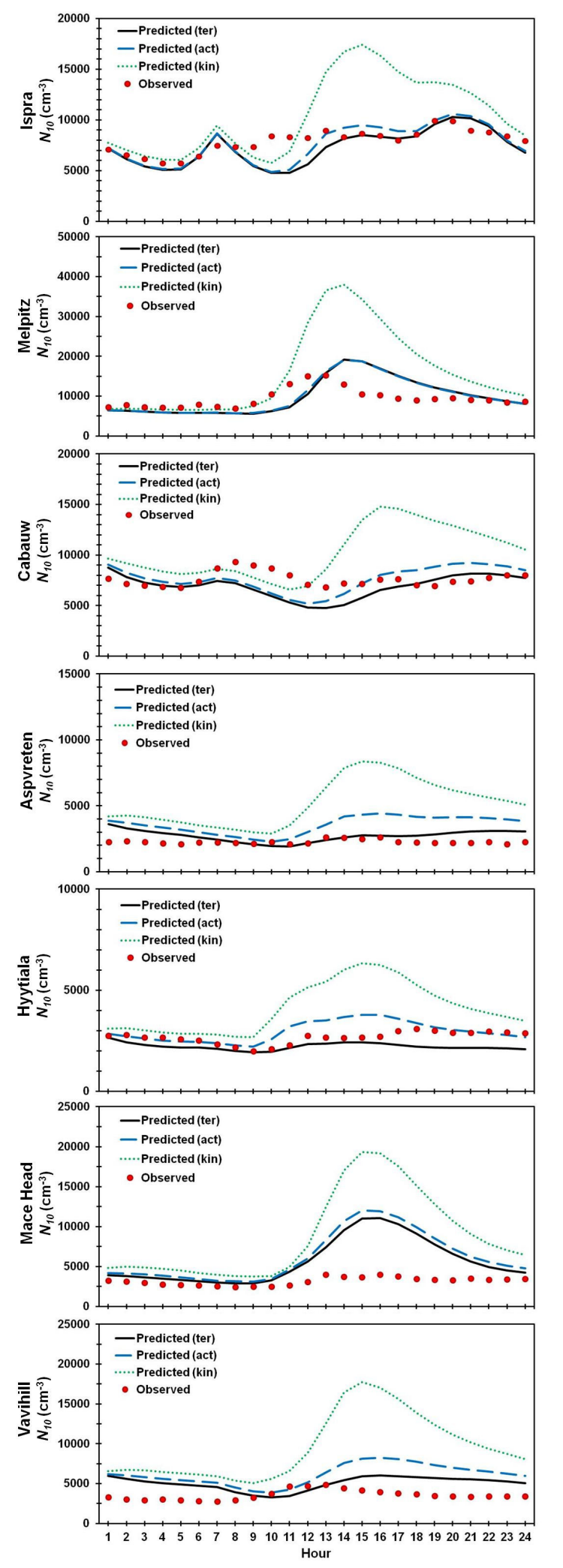

Fig. 5. Average diurnal profiles of particle number concentrations $\left(\mathrm{cm}^{-3}\right)$ above $10 \mathrm{~nm}$ in 7 measurement stations during May 2008.

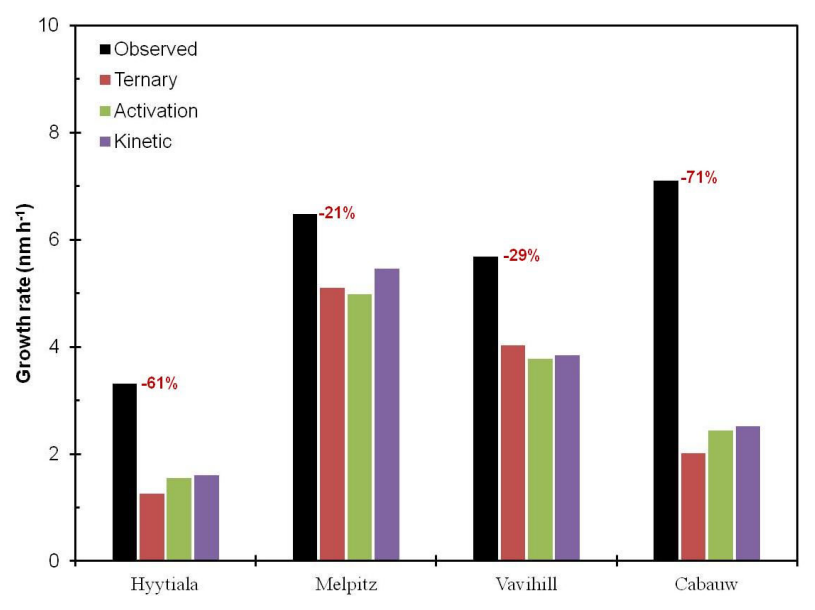

Fig. 6. Comparison of predicted vs. observed monthly median growth rates of particles (less than $20 \mathrm{~nm}$ ) during May 2008. The numbers in red color indicate the (ternary simulation) prediction error.

method described in Hirsikko et al. (2005). Figure 6 shows a comparison of the predicted growth rates against observed values from 4 sites reported in Manninen et al. (2010) during the May 2008 period. In all 4 sites, the model underpredicts the average growth rates probably due to insufficient organic vapor condensation in the current implementation of the model. The prediction error is larger in sites where organics are present in large concentrations (e.g. Hyytiala, Cabauw) and decreases significantly in sites where the sulfuric acid to organics mass ratio is higher (e.g. Melpitz). This is consistent with similar comparisons performed for the eastern US domain using PMCAMx-UF (Jung et al., 2010). For example in the sulfate rich area of Pittsburgh, PMCAMx-UF predicts an average growth rate of $7 \mathrm{~nm} \mathrm{~h}^{-1}$ during nucleation event days in July 2001 while the observed value was $10 \mathrm{~nm} \mathrm{~h}^{-1}$.

A sensitivity run was conducted to test the effect of organic vapor condensation on particle number concentrations above $100 \mathrm{~nm}$. The secondary OA production rate was artificially enhanced while a fraction of the new secondary organics was assigned zero volatility. The total OA concentration in the new simulation increased on average by a factor of 1.7. Enhancing the organics condensation resulted in an increase of $N_{100}$ by $10 \%$ on average over the whole domain. However, during nucleation event days the predicted increase was larger. In Melpitz for example, where frequent nucleation events are predicted (and observed), the sensitivity run increased $N_{100}$ by $30 \%$ which was the largest increase predicted in $N_{100}$ among the 7 sites studied during the simulation period. 
Table 3. Predicted impact (\%) of halving $\mathrm{SO}_{2}$ and $\mathrm{NH}_{3}$ emissions in particle number concentrations in Europe during May 2008.

\begin{tabular}{lrrrr}
\hline Emissions change & $N_{\text {tot }}$ & $N_{10}$ & $N_{50}$ & $N_{100}$ \\
\hline$-50 \% \mathrm{NH}_{3}$ & -15 & -9 & -3 & -2 \\
$-50 \% \mathrm{SO}_{2}$ & -21 & -19 & -18 & -25 \\
\hline
\end{tabular}

\subsection{Sensitivity to $\mathrm{SO}_{2}$ and $\mathrm{NH}_{3}$ emissions}

An important source of uncertainty in the predictions of particle number concentration is the gas phase emission levels of $\mathrm{NH}_{3}$ and $\mathrm{SO}_{2}$. Two sensitivity runs were conducted in which a uniform reduction of $50 \%$ in $\mathrm{NH}_{3}$ and $\mathrm{SO}_{2}$ emissions was applied in the domain. Table 3 shows the domain-average particle number concentration change $(\%)$ that the model predicts due to these emission reductions. Halving $\mathrm{NH}_{3}$ and $\mathrm{SO}_{2}$ emissions caused an average reduction in total particle number concentration by $15 \%$ and $21 \%$ respectively. The predicted changes, however, are not uniform throughout the size distribution. Reducing $\mathrm{NH}_{3}$ by $50 \%$ has a larger impact in the $1-10 \mathrm{~nm}$ size range reducing particle number by $21 \%$ and only a minor effect in particles larger than $50 \mathrm{~nm}(-3 \%)$ or $100 \mathrm{~nm}(-2 \%)$. Halving $\mathrm{SO}_{2}$ emissions on the other hand, affects primarily the $\mathrm{CCN}$ relevant sizes $(>100 \mathrm{~nm})$ reducing $N_{100}$ by $25 \%$ while resulting in approximately $-20 \%$ change of particle number in the $1-100 \mathrm{~nm}$ size range. This could have important implications for particle number emission control strategies. Reducing ammonia is almost as effective as reducing $\mathrm{SO}_{2}$ for ultrafine particles (16\% and $21 \%$ decrease of $N_{1-100}$, respectively) but at the same time has the co-benefit of not reducing the $\mathrm{CCN}$-sized particles which could potentially act as cooling agents of our planet.

\section{Conclusions}

PMCAMx-UF, a 3-D regional chemical transport model with detailed aerosol microphysics, was applied to the European domain for the first time, in order to simulate particle number concentrations during the month of May 2008 during which an intensive campaign of measurements was performed in Europe. The focus of this work was to better understand the relative contribution of direct emissions and new particle formation to regional aerosol number concentration in Europe during a photochemically active period. Model evaluation was performed against ground based hourly measurements from 7 sites. The model agrees encouragingly well with the particle number concentration ground measurements, reproducing more than $70 \%$ of the (hourly) data points for particles above $10 \mathrm{~nm}$ within a factor of 2 . A number of important conclusions arise from this study:
1. The model predicts nucleation events that occur over scales of hundreds up to thousands of kilometers mainly in the high $\mathrm{SO}_{2}$ areas of the Balkans and Southeast Europe as well as more localized events in west and central Europe.

2. Aerosol nucleation is predicted to increase the total particle number concentration by a factor of 20 or more in some of these wide areas and by a factor of 7 for particles larger than $10 \mathrm{~nm}$. For $N_{50}$, nucleation is responsible for an increase of more than $100 \%$ in Southeast Europe. The effect of nucleation in the lower troposphere on particle number above $100 \mathrm{~nm}$ is, on average, small with the exception of the Mediterranean area where the model predicts that nucleation can increase the number concentration of CCN-sized particles by up to $20 \%$.

3. On average, approximately $50 \%$ of particles above $10 \mathrm{~nm}$ are predicted to come from aerosol nucleation. Including nucleation in the simulation has a minor effect in the predictions of $N_{100}$ at all studied sites, ranging from $-4 \%$ to $+3 \%$ while the effect on $N_{50}$ is more pronounced only in sites that are influenced by local sources and have high aerosol number concentrations (i.e. Melpitz, Ispra and Cabauw). This effect may be underestimated though in the heavily forested areas due to weaknesses in our understanding of the role of biogenic SOA on the growth of fresh nanoparticles.

4. A systematic underprediction of $N_{100}$ at almost all studied sites implies the need for improvement of either the size distribution of the emissions and/or the growth of the ultrafine particles to this size range.

5. Results from the 3 nucleation mechanisms that were tested suggest that (i) the ternary mechanism performs better than the activation or the kinetic, and (ii) future particle number emission inventory efforts should focus on improvements in the diurnal and geographical split of the particle numbers emitted.

6. The model underpredicts the growth rates possibly due to insufficient organic vapors condensation in the current implementation of the model. The underprediction is low in sites where the sulfate to organics mass ratio is high (e.g. Melpitz).

7. Reducing emissions of ammonia and sulfur dioxide impact differently certain parts of the size distribution. This could have important implications for emission control strategies that seek to mitigate air pollution and climate change. 
Acknowledgements. This work was funded by the European Community's 7th Framework Programme EU projects PEGASOS (contract 265307) and EUCAARI (contract 34684). C. Fountoukis was partially supported by a Marie Curie International Reintegration Grant within the 7th European Community Framework Programme. We acknowledge the European Super-site for Atmospheric Aerosol Research (EUSAAR) for provision of data and the EU 7th Framework Programme project ACTRIS (contract 262254). Special thanks to M. Kulmala and P. Aalto for the Hyytiala data, S. G. Jennings and R. Dupuy for the Mace Head data, W. Birmili, B. Wehner, T. Tuch and A. Sonntag for the Melpitz data, H.-C. Hansson and P. Tunved for the Aspvreten data, E. Swietlicki and P. Roldin for the Vavihill data, C. Gruening for the Ispra data, J. S. Henzing and M. Moerman for the Cabauw data and Mikhail Sofiev for assistance with the fire emission inventory. Chlorofyll $a$ data used in this study were acquired using the GES-DISC Interactive Online Visualization ANd aNalysis Infrastructure (GIOVANNI) as part of the NASA's Goddard Earth Sciences (GES) Data and Information Services Center (DISC).

Edited by: A. Hofzumahaus

\section{References}

Adams, P. J. and Seinfeld, J. H.: Predicting global aerosol size distributions in general circulation models, J. Geophys. Res., 107, 4370, doi:10.1029/2001JD001010, 2002.

Anttila, T. and Kerminen V.-M.: Condensational growth of atmospheric nuclei by organic vapours, J. Aerosol Sci., 34, 41-61, doi:10.1016/S0021-8502(02)00155-6, 2003.

Asmi, A., Wiedensohler, A., Laj, P., Fjaeraa, A.-M., Sellegri, K., Birmili, W., Weingartner, E., Baltensperger, U., Zdimal, V., Zikova, N., Putaud, J.-P., Marinoni, A., Tunved, P., Hansson, H.C., Fiebig, M., Kivekäs, N., Lihavainen, H., Asmi, E., Ulevicius, V., Aalto, P. P., Swietlicki, E., Kristensson, A., Mihalopoulos, N., Kalivitis, N., Kalapov, I., Kiss, G., de Leeuw, G., Henzing, B., Harrison, R. M., Beddows, D., O'Dowd, C., Jennings, S. G., Flentje, H., Weinhold, K., Meinhardt, F., Ries, L., and Kulmala, M.: Number size distributions and seasonality of submicron particles in Europe 2008-2009, Atmos. Chem. Phys., 11, 5505-5538, doi:10.5194/acp-11-5505-2011, 2011.

Berndt, T., Stratmann, F., Sipilä, M., Vanhanen, J., Petäjä, T., Mikkilä, J., Grüner, A., Spindler, G., Lee Mauldin III, R., Curtius, J., Kulmala, M., and Heintzenberg, J.: Laboratory study on new particle formation from the reaction $\mathrm{OH}+\mathrm{SO}_{2}$ : influence of experimental conditions, $\mathrm{H}_{2} \mathrm{O}$ vapour, $\mathrm{NH}_{3}$ and the amine tert-butylamine on the overall process, Atmos. Chem. Phys., 10, 7101-7116, doi:10.5194/acp-10-7101-2010, 2010.

Birmili, W., Weinhold, K., Nordmann, S., Wiedensohler, A., Spindler, G., Müller, K., Herrmann, H., Gnauk, T., Pitz, M., Cyrys, J., Flentje, H., Nickel, C., Kuhlbusch, T. A. J., Löschau, G., Haase, D., Meinhardt, F., Schwerin, A., Ries, L., and Wirtz, K.: Atmospheric aerosol measurements in the German Ultrafine Aerosol Network (GUAN): Part 1 - soot and particle number size distributions, Gefahrst. Reinh. Luft, 69, 137-145, 2009.

Bonn, B., Kulmala, M., Riipinen, I., Sihto, S. L., and Ruuskanen, T. M.: How biogenic terpenes govern the correlation between sulfuric acid concentrations and new particle formation, J. Geophys. Res., 113, D12209, doi:10.1029/2007JD009327, 2008.
Donaldson, K., Li, X. Y., and MacNee, W.: Ultrafine (Nano-metre) particle mediated lung injury, J. Aerosol Sci., 29, 553-560, 1998.

Donaldson, K., David, B., Anna, C., Duffin, R., MacNee, W., Renwick, L., Tran, L., and Stone, V.: The pulmonary toxicology of ultrafine particles, Journal of Aerosol Medicine, 15, 213-220, 2002.

Eisele, F. L., Lovejoy, E. R., Kosciuch, E., Moore, K. F., Mauldin, R. L., Smith, J. N., McMurry, P. H., and Iida, K.: Negative atmospheric ions and their potential role in ion-induced nucleation, J. Geophys. Res., 111, D04305, doi:10.1029/2005JD006568, 2006.

Environ, User's guide to the comprehensive air quality model with extensions (CAMx), version 4.02, report, ENVIRON Int. Corp., Novato, Calif, available at: http://www.camx.com, 2003.

Fahey, K. M. and Pandis, S. N.: Optimizing model performance: Variable size resolution in cloud chemistry modeling, Atmos. Environ., 35, 4471-4478, doi:10.1016/S1352-2310(01)00224-2, 2001.

Fountoukis, C., Racherla, P. N., Denier van der Gon, H. A. C., Polymeneas, P., Charalampidis, P. E., Pilinis, C., Wiedensohler, A., Dall'Osto, M., O'Dowd, C., and Pandis, S. N.: Evaluation of a three-dimensional chemical transport model (PMCAMx) in the European domain during the EUCAARI May 2008 campaign, Atmos. Chem. Phys., 11, 10331-10347, doi:10.5194/acp11-10331-2011, 2011.

Gaydos, T. M., Stanier, C. O., and Pandis, S. N.: Modeling of in situ ultrafine atmospheric particle formation in the eastern United States, J. Geophys. Res., 110, D07S12, doi:10.1029/2004JD004683, 2005.

Gaydos, T., Pinder, R., Koo, B., Fahey, K., Yarwood, G., and Pandis, S. N.: Development and application of a three-dimensional Chemical Transport Model, PMCAMx, Atmos. Environ., 41, 2594-2611, 2007.

Guenther, A., Karl, T., Harley, P., Wiedinmyer, C., Palmer, P. I., and Geron, C.: Estimates of global terrestrial isoprene emissions using MEGAN (Model of Emissions of Gases and Aerosols from Nature), Atmos. Chem. Phys., 6, 3181-3210, doi:10.5194/acp-63181-2006, 2006.

Hirsikko, A., Laakso, L., Horrak, U., Aalto, P. P., Kerminen, V.-M., and Kulmala, M.: Annual and size dependent variation of growth rates and ion concentrations in boreal forest, Boreal Env. Res., 10, 357-369, 2005.

Jacobson, M. Z.: Development and application of a new air pollution modeling system, part II, Aerosol module structure and design, Atmos. Environ., 31, 131-144, 1997.

Jacobson, M. Z.: Analysis of aerosol interactions with numerical techniques for solving coagulation, nucleation, condensation, dissolution, and reversible chemistry among multiple size distributions, J. Geophys. Res., 107, 4366, doi:10.1029/2001JD002044, 2002.

Jung, J., Adams, P. J., and Pandis, S. N.: Simulating the size distribution and chemical composition of ultrafine particles during nucleation events, Atmos. Environ., 40, 2248-2259, doi:10.1016/j.atmosenv.2005.09.082, 2006.

Jung, J., Adams, P. J., and Pandis, S. N.: Evaluation of nucleation theories in a sulfur-rich environment, Aerosol Sci. Technol., 42, 495-504, doi:10.1080/02786820802187085, 2008.

Jung, J., Fountoukis, C., Adams, P. J., and Pandis, S. N.: Simulation of in situ ultrafine particle formation in the eastern United States using PMCAMx-UF, J. Geophys. Res., 115, D03203, 
doi:10.1029/2009JD012313, 2010.

Karydis, V. A., Tsimpidi, A. P., and Pandis, S. N.: Evaluation of a three-dimensional chemical transport model (PMCAMx) in the eastern United States for all four seasons, J. Geophys. Res., 112, D14211, doi:10.1029/2006JD007890, 2007.

Kerminen, V.-M., Virkkula, A., Hillamo, R., Wexler, A. S., and Kulmala, M.: Secondary organics and atmospheric cloud condensation nuclei production, J. Geophys. Res., 105, 9255-9264, doi:10.1029/1999JD901203, 2000.

Kerminen, V.-M., Petäjä, T., Manninen, H. E., Paasonen, P., Nieminen, T., Sipilä, M., Junninen, H., Ehn, M., Gagné, S., Laakso, L., Riipinen, I., Vehkamäki, H., Kurten, T., Ortega, I. K., Dal Maso, M., Brus, D., Hyvärinen, A., Lihavainen, H., Leppä, J., Lehtinen, K. E. J., Mirme, A., Mirme, S., Hõrrak, U., Berndt, T., Stratmann, F., Birmili, W., Wiedensohler, A., Metzger, A., Dommen, J., Baltensperger, U., Kiendler-Scharr, A., Mentel, T. F., Wildt, J., Winkler, P. M., Wagner, P. E., Petzold, A., Minikin, A., Plass-Dülmer, C., Pöschl, U., Laaksonen, A., and Kulmala, M.: Atmospheric nucleation: highlights of the EUCAARI project and future directions, Atmos. Chem. Phys., 10, 10829-10848, doi:10.5194/acp-10-10829-2010, 2010.

Kirkby, J., Curtius, J., Almeida, J., Dunne, E., Duplissy, J., Ehrhart, S., Franchin, A., Gagne, S., Ickes, L., Kurten, A., Kupc, A., Metzger, A., Riccobono, F., Rondo, L., Schobesberger, S., Tsagkogeorgas, G., Wimmer, D., Amorim, A., Bianchi, F., Breitenlechner, M., David, A., Dommen, J., Downard, A., Ehn, M., Flagan, R. C., Haider, S., Hansel, A., Hauser, D., Jud, W., Junninen, H., Kreissl, F., Kvashin, A., Laaksonen, A., Lehtipalo, K., Lima, J., Lovejoy, E. R., Makhmutov, V., Mathot, S., Mikkila, J., Minginette, P., Mogo, S., Nieminen, T., Onnela, A., Pereira, P., Petaja, T., Schnitzhofer, R., Seinfeld, J. H., Sipila, M., Stozhkov, Y., Stratmann, F., Tome, A., Vanhanen, J., Viisanen, Y., Vrtala, A., Wagner, P. E., Walther, H., Weingartner, E., Wex, H., Winkler, P. M., Carslaw, K. S., Worsnop, D. R., Baltensperger, U., Kulmala, M.: Role of sulphuric acid, ammonia and galactic cosmic rays in atmospheric aerosol nucleation, Nature, 476, 429433, doi:10.1038/nature10343, 2011.

Kuang, C., McMurry, P. H., McCormick, A. V., and Eisele, F. L.: Dependence of nucleation rates on sulfuric acid vapor concentration in diverse atmospheric locations, J. Geophys. Res., 113, D10209, doi:10.1029/2007JD009253, 2008.

Kulmala, M., Dal Maso, M., Mäkelä, J. M., Pirjola, L., Väkevä, M., Aalto, P., Miikkulainen, P., Hämeri, K., and O'Dowd, C. D.: On the formation, growth and composition of nucleation mode particles, Tellus B 53, 479-490, 2001.

Kulmala, M., Vehkamäki, H., Petäjä, T., Dal Maso, M., Lauri, A., Kerminen, V.-M., Birmili, W., and McMurry, P. H.: Formation and growth rates of ultrafine atmospheric particles: A review of observations, J. Aerosol Sci., 35, 143-176, doi:10.1016/j.jaerosci.2003.10.003, 2004.

Kulmala, M., Lehtinen, K. E. J., and Laaksonen, A.: Cluster activation theory as an explanation of the linear dependence between formation rate of $3 \mathrm{~nm}$ particles and sulphuric acid concentration, Atmos. Chem. Phys., 6, 787-793, doi:10.5194/acp-6-787-2006, 2006.

Kulmala, M., Asmi, A., Lappalainen, H. K., Carslaw, K. S., Pöschl, U., Baltensperger, U., Hov, Ø., Brenquier, J.-L., Pandis, S. N., Facchini, M. C., Hansson, H.-C., Wiedensohler, A., and O'Dowd, C. D.: Introduction: European Integrated Project on
Aerosol Cloud Climate and Air Quality interactions (EUCAARI) - integrating aerosol research from nano to global scales, Atmos. Chem. Phys., 9, 2825-2841, doi:10.5194/acp-9-2825-2009, 2009.

Kulmala, M., Asmi, A., Lappalainen, H. K., Baltensperger, U., Brenguier, J.-L., Facchini, M. C., Hansson, H.-C., Hov, Ø., O'Dowd, C. D., P "oschl, U., Wiedensohler, A., Boers, R., Boucher, O., de Leeuw, G., Denier van der Gon, H. A. C., Feichter, J., Krejci, R., Laj, P., Lihavainen, H., Lohmann, U., McFiggans, G., Mentel, T., Pilinis, C., Riipinen, I., Schulz, M., Stohl, A., Swietlicki, E., Vignati, E., Alves, C., Amann, M., Ammann, M., Arabas, S., Artaxo, P., Baars, H., Beddows, D. C. S., Bergström, R., Beukes, J. P., Bilde, M., Burkhart, J. F., Canonaco, F., Clegg, S. L., Coe, H., Crumeyrolle, S., D’Anna, B., Decesari, S., Gilardoni, S., Fischer, M., Fjaeraa, A. M., Fountoukis, C., George, C., Gomes, L., Halloran, P., Hamburger, T., Harrison, R. M., Herrmann, H., Hoffmann, T., Hoose, C., Hu, M., Hyvärinen, A., Hõrrak, U., Iinuma, Y., Iversen, T., Josipovic, M., Kanakidou, M., Kiendler-Scharr, A., Kirkevåg, A., Kiss, G., Klimont, Z., Kolmonen, P., Komppula, M., Kristjánsson, J.-E., Laakso, L., Laaksonen, A., Labonnote, L., Lanz, V. A., Lehtinen, K. E. J., Rizzo, L. V., Makkonen, R., Manninen, H. E., McMeeking, G., Merikanto, J., Minikin, A., Mirme, S., Morgan, W. T., Nemitz, E., O’Donnell, D., Panwar, T. S., Pawlowska, H., Petzold, A., Pienaar, J. J., Pio, C., Plass-Duelmer, C., Prévôt, A. S. H., Pryor, S., Reddington, C. L., Roberts, G., Rosenfeld, D., Schwarz, J., Seland, Ø., Sellegri, K., Shen, X. J., Shiraiwa, M., Siebert, H., Sierau, B., Simpson, D., Sun, J. Y., Topping, D., Tunved, P., Vaattovaara, P., Vakkari, V., Veefkind, J. P., Visschedijk, A., Vuollekoski, H., Vuolo, R., Wehner, B., Wildt, J., Woodward, S., Worsnop, D. R., van Zadelhoff, G.-J., Zardini, A. A., Zhang, K., van Zyl, P. G., Kerminen, V.-M., S Carslaw, K., and Pandis, S. N.: General overview: European Integrated project on Aerosol Cloud Climate and Air Quality interactions (EUCAARI) - integrating aerosol research from nano to global scales, Atmos. Chem. Phys., 11, 13061-13143, doi:10.5194/acp11-13061-2011, 2011.

Kurtén, T., Loukonen, V., Vehkamäki, H., and Kulmala, M.: Amines are likely to enhance neutral and ion-induced sulfuric acid-water nucleation in the atmosphere more effectively than ammonia, Atmos. Chem. Phys., 8, 4095-4103, doi:10.5194/acp-8-4095-2008, 2008.

Laakso, L., Makela, J. M., Pirjola, L., and Kulmala, M.: Model studies on ion - induced nucleation in the atmosphere, J. Geophys. Res., 107, 4427, doi:10.1029/2002JD002140, 2002.

Lovejoy, E. R., Curtius, J., and Froyd, K. D.: Atmospheric ioninduced nucleation of sulfuric acid and water, J. Geophys. Res., 109, D08204, doi:10.1029/2003JD004460, 2004.

Manninen, H. E., Nieminen, T., Asmi, E., Gagné, S., Häkkinen, S., Lehtipalo, K., Aalto, P., Vana, M., Mirme, A., Mirme, S., Hõrrak, U., Plass-Dülmer, C., Stange, G., Kiss, G., Hoffer, A., Töro, N., Moerman, M., Henzing, B., de Leeuw, G., Brinkenberg, M., Kouvarakis, G. N., Bougiatioti, A., Mihalopoulos, N., O’Dowd, C., Ceburnis, D., Arneth, A., Svenningsson, B., Swietlicki, E., Tarozzi, L., Decesari, S., Facchini, M. C., Birmili, W., Sonntag, A., Wiedensohler, A., Boulon, J., Sellegri, K., Laj, P., Gysel, M., Bukowiecki, N., Weingartner, E., Wehrle, G., Laaksonen, A., Hamed, A., Joutsensaari, J., Petäjä, T., Kerminen, V.-M., and Kulmala, M.: EUCAARI ion spectrometer measurements at 
12 European sites -analysis of new particle formation events, Atmos. Chem. Phys., 10, 7907-7927, doi:10.5194/acp-10-79072010, 2010.

McMurry, P. H. and Friedlander, S. K.: New particle formation in the presence of an aerosol, Atmos. Environ., 13, 1635-1651, 1979.

Merikanto, J., Napari, I., Vehkamaki, H, Anttila, T., and Kulmala, M.: New parameterization of sulfuric acid-ammonia-water ternary nucleation rates at tropospheric conditions, J. Geophys. Res., 112, D15207, doi:10.1029/2006JD007977, 2007.

Merikanto, J., Spracklen, D. V., Mann, G. W., Pickering, S. J., and Carslaw, K. S.: Impact of nucleation on global CCN, Atmos. Chem. Phys., 9, 8601-8616, doi:10.5194/acp-9-8601-2009, 2009.

Metzger, A., Verheggen, B., Dommen, J., Duplissy, J., Prevot, A. S. H., Weingartner, E., Riipinen, I., Kulmala, M., Spracklen, D. V., Carslaw, K. S., and Baltensperger, U.: Evidence for the role of organics in aerosol particle formation under atmospheric conditions, P. Natl. Acad. Sci. USA, 107, 6646-6651, 2010.

Napari, I., Noppel, M., Vehkamaki, H., and Kulmala, M.: Parameterization of ternary nucleation rates for $\mathrm{H}_{2} \mathrm{SO}_{4}-\mathrm{NH}_{3}-\mathrm{H}_{2} \mathrm{O}$ vapors, J. Geophys. Res., 107, 4381, doi:10.1029/2002JD002132, 2002.

Nieminen, N., Manninen, H. E., Sihto, S.-L., Yli-Juuti, T., Mauldin, R. L., Petaja, T., Riipinen, I., Kerminen, V.-M., and Kulmala, M.: Connection of sulfuric acid to atmospheric nucleation in boreal forest, Environ. Sci. Technol., 43, 4715-4721, doi:10.1021/es803152j, 2009.

O’Dowd, C. D., Langmann, B., Varghese, S., Scannell, C., Ceburnis, D., and Facchini, M. C.: A combined organic-inorganic sea-spray source function, Geophys. Res. Lett., 35, L01801, doi:10.1029/2007GL030331, 2008.

Paasonen, P., Sihto, S.-L., Nieminen, T., Vuollekoski, H., Riipinen, I., Plass-Dulmer, C.,Berresheim, H., Birmili, W., and Kulmala, M.: Connection between new particle formation and sulphuric acid at Hohenpeissenberg (Germany) including the influence of organic compounds, Boreal Environ. Res., 14, 616-629, 2009.

Paasonen, P., Nieminen, T., Asmi, E., Manninen, H. E., Petäjä, T., Plass-Dülmer, C., Flentje, H., Birmili, W., Wiedensohler, A., Hõrrak, U., Metzger, A., Hamed, A., Laaksonen, A., Facchini, M. C., Kerminen, V.-M., and Kulmala, M.: On the roles of sulphuric acid and low-volatility organic vapours in the initial steps of atmospheric new particle formation, Atmos. Chem. Phys., 10, 11223-11242, doi:10.5194/acp-10-11223-2010, 2010.

Pierce, J. R. and Adams, P. J.: A computationally efficient aerosol nucleation/condensation method: Pseudo-steadystate sulfuric acid, Aerosol Sci. Technol., 43, 216-226, doi:10.1080/02786820802587896, 2009.

Pierce, J., Theodoritsi, G., Adams, P., and Pandis, S. N.: Parameterization of the effect of sub-grid scale aerosol dynamics on aerosol number emission rates, J. Aerosol Sci., 40, 385-393, 2009.

Pierce, J. R., Riipinen, I., Kulmala, M., Ehn, M., Petäjä, T., Junninen, H., Worsnop, D. R., and Donahue, N. M.: Quantification of the volatility of secondary organic compounds in ultrafine particles during nucleation events, Atmos. Chem. Phys., 11, 90199036, doi:10.5194/acp-11-9019-2011, 2011.

Riipinen, I., Sihto, S.-L., Kulmala, M., Arnold, F., Dal Maso, M., Birmili, W., Saarnio, K., Teinilä, K., Kerminen, V.-M., Laaksonen, A., and Lehtinen, K. E. J.: Connections between atmo- spheric sulphuric acid and new particle formation during QUEST III-IV campaigns in Heidelberg and Hyytiälä, Atmos. Chem. Phys., 7, 1899-1914, doi:10.5194/acp-7-1899-2007, 2007.

Reddington, C. L., Carslaw, K. S., Spracklen, D. V., Frontoso, M. G., Collins, L., Merikanto, J., Minikin, A., Hamburger, T., Coe, H., Kulmala, M., Aalto, P., Flentje, H., Plass-Dülmer, C., Birmili, W., Wiedensohler, A., Wehner, B., Tuch, T., Sonntag, A., O’Dowd, C. D., Jennings, S. G., Dupuy, R., Baltensperger, U., Weingartner, E., Hansson, H.-C., Tunved, P., Laj, P., Sellegri, K., Boulon, J., Putaud, J.-P., Gruening, C., Swietlicki, E., Roldin, P., Henzing, J. S., Moerman, M., Mihalopoulos, N., Kouvarakis, G., Ždímal, V., Zíková, N., Marinoni, A., Bonasoni, P., and Duchi, R.: Primary versus secondary contributions to particle number concentrations in the European boundary layer, Atmos. Chem. Phys., 11, 12007-12036, doi:10.5194/acp-11-12007-2011, 2011. Sihto, S.-L., Kulmala, M., Kerminen, V.-M., Dal Maso, M., Petäjä, T., Riipinen, I., Korhonen, H., Arnold, F., Janson, R., Boy, M., Laaksonen, A., and Lehtinen, K. E. J.: Atmospheric sulphuric acid and aerosol formation: implications from atmospheric measurements for nucleation and early growth mechanisms, Atmos. Chem. Phys., 6, 4079-4091, doi:10.5194/acp-6-4079-2006, 2006.

Sioutas, C., Delfino, R. J., and Singh, M.: Exposure assessment for atmospheric ultrafine particles (UFPs) and implications in epidemiologic research, Environ. Health Perspect., 113, 947-955, doi:10.1289/ehp.7939, 2005.

Sipilä, M., Berndt, T., Petaja, T., Brus, D., Vanhanen, J., Stratmann, F., Patokoski, J., Mauldin, R. L., Hyvarinen, A.P., Lihavainen, H., and Kulmala, M.: The role of sulfuric acid in atmospheric nucleation, Science, 327, 1243-1246, doi:10.1126/science.1180315, 2010.

Skamarock, W. C., Klemp, J. B., Dudhia, J., Gill, D. O., Barker, D. M., Wang, W., and Powers, J. G.: A Description of the Advanced Research WRF Version 2, NCAR Technical Note (http://www. mmm.ucar.edu/wrf/users/docs/arw_v2.pdf), 2005.

Smith, J. N., Barsanti, K. C., Friedli, H. R., Ehn, M., Kulmala, M., Collins, D. R., Scheckman, J. H., Williams, B. J., and McMurry, P. H.: Observations of aminium salts in atmospheric nanoparticles and possible climatic implications, P. Natl. Acad. Sci. USA, 107, 663-6639, 2010.

Sofiev, M., Vankevich, R., Lanne, M., Koskinen, J., and Kukkonen, J.: On integration of a Fire Assimilation System and a chemical transport model for near-real-time monitoring of the impact of wild-land fires on atmospheric composition and air quality, Modelling, Monitoring and Management of Forest Fires, WIT Transactions on Ecology and the Environment, 119, 343-351, 2008a.

Sofiev, M., Lanne, M., Vankevich, R., Prank, M., Karppinen, A., and Kukkonen, J.: Impact of wild-land fires on European air quality in 2006-2008, Modelling, Monitoring and Management of Forest Fires, WIT Transactions on Ecology and the Environment, 119, 353-361, 2008b.

Sotiropoulou, R. E. P., Tagaris, E., Pilinis, C., Anttila, T., and Kulmala, M.: Modeling new particle formation during air pollution episodes: Impacts on aerosol and cloud condensation nuclei, Aerosol Sci. Technol., 40, 557-572, doi:10.1080/02786820600714346, 2006.

Spracklen, D. V., Pringle, K. J., Carslaw, K. S., Chipperfield, M. P., and Mann, G. W.: A global off-line model of size- 
resolved aerosol microphysics: I. Model development and prediction of aerosol properties, Atmos. Chem. Phys., 5, 22272252, doi:10.5194/acp-5-2227-2005, 2005a.

Spracklen, D. V., Pringle, K. J., Carslaw, K. S., Chipperfield, M. P., and Mann, G. W.: A global off-line model of size-resolved aerosol microphysics: II. Identification of key uncertainties, Atmos. Chem. Phys., 5, 3233-3250, doi:10.5194/acp-5-3233-2005, $2005 b$

Spracklen, D. V., Carslaw, K. S., Kulmala, M., Kerminen, V.-M., Mann, G. W., and Sihto, S.-L.: The contribution of boundary layer nucleation events to total particle concentrations on regional and global scales, Atmos. Chem. Phys., 6, 5631-5648, doi:10.5194/acp-6-5631-2006, 2006.

Spracklen, D. V., Carslaw, K. S., Kulmala, M., Kerminen, V.-M., Sihto, S.-L., Riipinen, I., Merikanto, J., Mann, G. W., Chipperfield, M. P., Wiedensohler, A., Birmili, W., and Lihavainen, H.: Contribution of particle formation to global cloud condensation nuclei concentrations, Geophys. Res. Lett., 35, L06808, doi:10.1029/2007GL033038, 2008.

Spracklen, D. V., Carslaw, K. S., Merikanto, J., Mann, G. W., Reddington, C. L., Pickering, S., Ogren, J. A., Andrews, E., Baltensperger, U., Weingartner, E., Boy, M., Kulmala, M., Laakso, L., Lihavainen, H., Kivekäs, N., Komppula, M., Mihalopoulos, N., Kouvarakis, G., Jennings, S. G., O’Dowd, C., Birmili, W., Wiedensohler, A., Weller, R., Gras, J., Laj, P., Sellegri, K., Bonn, B., Krejci, R., Laaksonen, A., Hamed, A., Minikin, A., Harrison, R. M., Talbot, R., and Sun, J.: Explaining global surface aerosol number concentrations in terms of primary emissions and particle formation, Atmos. Chem. Phys., 10, 4775-4793, doi:10.5194/acp-10-4775-2010, 2010.

Stanier, C. O., Khlystov, A. Y., and Pandis, S. N.: Nucleation events during the Pittsburgh Air Quality Study: Description and relation to key meteorological, gas phase, and aerosol parameters, Aerosol Sci. Technol., 38, 1-12, 2004.

Trivitayanurak, W., Adams, P. J., Spracklen, D. V., and Carslaw, K. S.: Tropospheric aerosol microphysics simulation with assimilated meteorology: model description and intermodel comparison, Atmos. Chem. Phys., 8, 3149-3168, doi:10.5194/acp-83149-2008, 2008.
Vehkamäki, H., Kulmala, M., Napari, I., Lehtinen, K. E. J., Timmreck, C., Noppel, M., and Laaksonen, A.: An improved parameterization for sulfuric acid-water nucleation rates for tropospheric and stratospheric conditions, J. Geophys. Res., 107, 4622, doi:10.1029/2002JD002184, 2002.

Vehkamaki, H., Napari, I., and Kulmala, M.: Stable ammonium bisulfate clusters in the atmosphere, Phys. Rev. Lett., 93, 148501, doi:10.1103/PhysRevLett.93.148501, 2004.

Visschedijk, A. J. H., Zandveld, P., and Denier van der Gon, H. A. C.: TNO Report 2007 A-R0233/B: A high resolution gridded European emission database for the EU integrated project GEMS, Netherlands, Organization for Applied Scientific Research, 2007.

Weber, R. J., Marti, J. J., McMurry, P. H., Eisele, F. L., Tanner, T. J., and Jefferson, A.: Measured atmospheric new particle formation rates: Implications for nucleation mechanisms, Chem. Eng. Commun., 151, 53-64, 1996.

Yu, F.: Effect of ammonia on new particle formation: A kinetic $\mathrm{H}_{2} \mathrm{SO}_{4}-\mathrm{H}_{2} \mathrm{O}-\mathrm{NH}_{3}$ nucleation model constrained by laboratory measurements, J. Geophys. Res., 111, D01204, doi:10.1029/2005JD005968, 2006a.

Yu, F.: From molecular clusters to nanoparticles: second-generation ion-mediated nucleation model, Atmos. Chem. Phys., 6, 51935211, doi:10.5194/acp-6-5193-2006, 2006b.

Yu, F. and Luo, G.: Simulation of particle size distribution with a global aerosol model: contribution of nucleation to aerosol and CCN number concentrations, Atmos. Chem. Phys., 9, 76917710, doi:10.5194/acp-9-7691-2009, 2009.

Zhang, Y., McMurry, P. H., Yu, F., and Jacobson, M. Z.: A comparative study of nucleation parameterizations: 1 . Examination and evaluation of the formulations, J. Geophys. Res., 115, D20212, doi:10.1029/2010JD014150, 2010.

Zhao, J., Smith, J. N., Eisele, F. L., Chen, M., Kuang, C., and McMurry, P. H.: Observation of neutral sulfuric acid-amine containing clusters in laboratory and ambient measurements, Atmos. Chem. Phys., 11, 10823-10836, doi:10.5194/acp-1110823-2011, 2011. 